Skidmore College

Creative Matter

English Faculty Scholarship

English

1998

\title{
Someone's in the Garden with Eve: Race, Religion, and the American Fall
}

Mason Stokes

SkidmoreCollege, mstokes@skidmore.edu

Follow this and additional works at: https://creativematter.skidmore.edu/eng_fac_schol

Part of the American Studies Commons, and the Feminist, Gender, and Sexuality Studies Commons

\section{Recommended Citation}

Stokes, Mason. “Someone's in the Garden with Eve: Race, Religion, and the American Fall." American Quarterly, vol. 50, no. 4, 1998, pp. 718-744.

This Article is brought to you for free and open access by the English at Creative Matter. It has been accepted for inclusion in English Faculty Scholarship by an authorized administrator of Creative Matter. For more information, please contact jluo@skidmore.edu. 


\title{
Someone's in the Garden with Eve: Race, Religion, and the American Fall
}

\author{
MASON STOKES \\ Skidmore College
}

America's so-called "Negro problem" has always been, at the same time, a theological problem. W. E. B. Du Bois put this clearly when, in 1913, he called the church "the strongest seat of racial and color prejudice." "The Negro problem is the test of the church," he wrote, and since American Christianity "was the bulwark of American slavery," it is hard to imagine that Du Bois was very optimistic about the outcome of this test. ${ }^{2} \mathrm{He}$ does allow himself a touch of optimism, however, when, in the same essay, he muses upon the historical interrelation between religious racism and American science. "Even the rock of 'Science,", he writes, "on which the white church rested with such beautiful faith, hoping to prove the majority of humanity inhuman, . . even this Rock of Ages is falling before honest investigation."

While this rock of science may have been crumbling in 1913, sixty years earlier it was just beginning to form. In "The Claims of the Negro Ethnologically Considered" (1854), Frederick Douglass launched a sustained attack against the mid-century vogue of American ethnology, the scientific school of so-called racial difference. Armed with a theory of multiple creations-polygenesis-the ethnologists offered a new weapon to the arsenal of pro-slavery discourse, one that attempted, in Douglass's words, to "read the Negro out of the human family."4 The theory of polygenesis proved tremendously attractive to pro-slavery theologians, for it sketched a world in which some "human families" were better descended than others. Some could trace themselves back to Adam and Eve, and those who could not were then Biblically

Mason Stokes is a visiting assistant professor of English at Skidmore College. This article is part of his larger study of white-supremacist fictions, forthcoming from Duke University Press. 
constituted as appropriate material for slavery. The ethnologists offered scientific sanction for a Biblical theory of slavery at a time when the tension between science and religion was on the rise. Scientific "discoveries" often contradicted Biblical "truth," creating a double bind for so-called Christian slaveholders and their apologists. The ethnologists offered one way out of this double bind by giving theological racism a Biblically acceptable narrative of polygenesis. ${ }^{5}$

In the years following Douglass's essay, scores of American scientists and theologians returned to the Biblical scene of the Garden of Eden as the setting for their racist imaginings of "the Negro's" place (or more accurately, lack of place) in the human family. In so doing, they found a black presence at the scene of the temptation, a black man where the snake should have been. Concerned as they were with the question of so-called racial purity, this black man's proximity to Eve was cause for alarm.

Recently collected in Anti-Black Thought, 1863-1925: "The Negro Problem," edited by John David Smith, these Eden revisionists offer a window into the process by which science and religion came to mediate and shape white America's attempt, during the latter half of the nineteenth century, to rid itself once and for all of "the Negro." The theo-science that resulted from this attempt has a great deal to tell us about the shaky and often surreal infrastructure of whiteness as a form of racial, sexual, and intellectual anxiety.

$$
* * *
$$

Douglass was quick to recognize the dubious entanglement of antiblack science with conventional Christian theology. In "The Claims of the Negro" Douglass foregrounds the fundamental biases at the heart of so-called scientific objectivity. "It is the province of prejudice to blind," Douglass writes,

and scientific writers, not less than others, write to please, as well as to instruct, and even unconsciously to themselves, (sometimes,) sacrifice what is true to what is popular. Fashion is not confined to dress; but extends to philosophy as well. ${ }^{6}$

With characteristic sarcasm, Douglass dismisses "all the scientific moonshine that would connect men with monkeys," and calls for the nation's moral growth to keep up with its alleged "increase of knowledge." 
Douglass recognizes, however, that it is not simply "prejudice" that produces faulty science, but prejudice mixed with a misappropriation of Biblical authority. The power of the Bible in the war over the racial past produced one of the central ironies in this debate, since Douglass, through his Christian faith, proceeds from assumptions and goals similar to those of the ethnologists he was debunking. He realizes that the question of the unity of mankind will in part be decided by what "reflects the most glory upon the wisdom, power, and goodness of the Author of all existence." "The credit of the Bible is at stake," he writes, and "the value of that sacred Book ... must be materially affected, by the decision of the question." 8

Douglass's allegiance to the Bible puts him in the rather strange company of the Negrophobic Charles Carroll, whose writings were dedicated to proving that the Negro was a "beast." "Inasmuch as my views of the negro were based upon the Bible," Carroll writes, "I realized that it was necessary to show that the scriptures were in absolute harmony with the sciences at every point." And though Carroll's goal of a perfect harmony between science and religion might seem overly optimistic, the force of white racism was capable of making the most discordant of notes blend perfectly. In a culture eager to prove the Negro's inferiority and inhumanity, this harmonizing would be less difficult than might be imagined. ${ }^{10}$

The science we are talking about here was of dubious shape and intention. Ethnology, called by Ephraim Squier in 1849 the "science of the age," was largely a hodgepodge of anthropology, Egyptology, and craniology. It was designed to investigate, in Squier's words, "the superiority of certain families over others," and "to what extent they may assimilate with, to what repel each other, and how their relations may be adjusted so as to produce the greatest attainable advantage to both." "l Beginning with Dr. Samuel Morton's Crania Americana, published in 1839, scientists transformed an American obsession with physical difference into a science of so-called racial difference. With an eye to hair, lips, foreheads, and feet, these scientists articulated a theory that equated morphological characteristics with mental and emotional possibility. These men legitimated with science what could be called the common sense racism of their cultural moment.

And yet, the theory of polygenesis that grew out of this science seemed to call into radical question the Mosaic account of creation found in Genesis. How could polygenesis possibly be accepted in a 
theologically dogmatic society-one like the South, which, for all its interest in the latest scientific theories, always judged those theories against the presumed greater authority of Biblical truth? The tension between science and theology that so concerned Du Bois and Douglass characterized and ultimately shaped much of the debate over racial difference and slavery in the nineteenth century. At issue was a complicated struggle for various forms of sanction and accreditation, as thinkers like Nott, Aggasiz, Morton, and DeGobineau struggled to navigate their way through a maze of conflicting authority. Science and religion became the Scylla and Charybdis of the "race question" in mid-nineteenth-century America. Ethnologists gleefully waged war against the parsons, and yet worked in constant fear of the parsons' very real cultural power. Sometimes happy in their roles as martyrs to "truth," these scientists were continually frustrated by the power of the Church."

And in terms of the larger argument over slavery, the power of religion functioned in anything but a straight line. As William Stanton has argued, in the days before the Civil War, the South's religious dogmatism denied it a scientific justification for its slave-holding. ${ }^{13}$ Had southern plantation owners fully accepted the theory of polygenesis, their argument in favor of slavery could have been supported by the cold "facts" of science. But to accept these facts would have meant to deny the literal truth of the Genesis story, and, in the long run, the South's refusal to do so denied it very little.

For if science offered one way of supporting the enslavement of blacks, religion, if examined in the "proper light," could offer another. What the South lost in its reluctance to embrace new scientific "evidence" of racial difference and so-called black inferiority, it made up for in the stories of the Bible, where one could find such rich nuggets as Noah's strange curse on Canaan, the Flood, the destruction of Sodom, and other stories of Biblical apocalypse. In the often surreal narratives of nineteenth-century Biblical scholarship, these stories, with all their misreadings, bear the brunt of supporting the anti-black, pro-slavery theorists in their theo-political quest for racial purity.

But it was not just to Canaan and his troubled family that these theorists turned for their evidence of black inferiority. Rather, they started "in the beginning," at the story of the Fall. From as early as 1860 , various writers located their racist polemics in the heart of the Garden-at the site of Eve's temptation. Devoting countless pages to 
minute exegeses of the tempter's true identity, these authors, with various permutations on the theme, arrived at a reading of the temptation in which the "serpent" was either an ape or a human, often black, and usually male.

This rereading accomplished at least two significant things. First, if the tempter was a black man, then obviously black men existed either contemporaneous with or prior to Adam and Eve. The proponents of polygenesis had made this a narrative necessity. Second, and in my view more importantly, this reading of the temptation of Eve worked to buttress hysteria over the issue of miscegenation, or in the nineteenthcentury parlance, amalgamation. If Eve's tempter was a black man (or a black woman), then original sin was not located in her eating of the apple, but in her far more grievous crime of heeding the seductive words of a black tempter. Thus miscegenation becomes the reason for the Fall, just as it was interpreted to be the cause of subsequent Biblical apocalypses. By locating a black tempter in the Garden of Eden, antiblack theorists created a richly textured and narratively dense web of pro-slavery theology, and fueled the post-war fires of amalgamation hysteria. Just as Uncle Tom's Cabin functioned as a mid-century appeal to save a slave-ridden and thus destruction-bound nation, these theorists of the Garden constructed their own allegorical entreaty, one that showed the nation on the same path that previously led to the Fall, the Flood, and various plagues by fire and locust. Amalgamation, miscegenation, inter-marriage, integration-these were the contemporary sins that would surely seal the nation's doom. ${ }^{14}$

In the pages that follow, I will examine a few of the most important moments in this period of Biblical exegesis, paying particular attention to the ways in which the concerns and fears of the post-war South found themselves projected back to the Garden-back to the mysterious relationship between Eve, "our" great white mother, and that darker force, capable of bending her desires to his own.

$$
* * *
$$

Primary responsibility for the propagation of this racist Eden mythos belongs to a Nashville publisher named Buckner Payne, who in 1867, under the pseudonym of "Ariel," published a pamphlet with the descriptive title, The Negro: What is His Ethnological Status? Is He the Progeny of Ham? Is He a Descendant of Adam and Eve? Has He a 
Soul? Or Is He a Beast in God's Nomenclature? What Is His Status as Fixed by God in Creation? What Is His Relation to the White Race? ${ }^{15}$ In his efforts to prove that "the Negro" is (and always has been) a beast, Ariel reawakened the controversy over polygenesis, claiming disingenuously that his work had nothing to do with politics. Harrison Berry, a black respondent to Ariel's work, got to the heart of the matter when he wrote that "it is too apparent to be doubted that the whole fabrication is founded on the interest of the great diabolical slave power, making the enslavement of the Negro justifiable on the hypothesis of his being a beast."16

Because Ariel's argument figures so prominently in the larger debate, it is worth pausing to summarize its main components: (1) Noah's curse did not make Ham a Negro; (2) since Noah and his wife were both white and "perfect in their genealogy," and since Adam and Eve were also white, it is impossible that either pair could be "the progenitors of the kinky-headed, black-skinned negroes of this day"; (3) this being the case, the Negro was of necessity created prior to Adam, along with "the other beasts and cattle," and is "a beast in God's nomenclature; and being a beast, was under Adam's rule and dominion, and, like all other beasts or animals, has no soul."17

Ariel's ultimate conclusion is that the tempter in the garden "was a beast, a talking beast" (45). The commerce between Eve and the Negro beast — stated but not unpacked by Ariel—stands as the Ur-sin, the first cause of the Fall. And it stands at the root of Ariel's story. Shifting from Biblical exegesis to contemporary diatribe, Ariel concludes by reminding the reader that

a man can not commit so great an offense against his race, against his country, against his God, in any other way, as to give his daughter in marriage to a negro-a beast-or to take one of their females for his wife. (48)

If the country continues to engage in this practice, warns Ariel, then it can expect the same fate faced by the antediluvians: "the states or people that favor this equality and amalgamation of the white and black races, God will exterminate" (48). The South may have lost the war, but in Ariel's optimistic view, its real troubles were just beginning.

As the Ariel debate proceeded its terms became somewhat more lucid, though no less surreal. One of the more interesting and strangely compelling responses to Ariel's work is Caliban: A Sequel to "Ariel" 
(1868), written under the pseudonym, appropriately enough, of Prospero. ${ }^{18}$ Prospero begins by demonstrating Genesis's account of not one, but two primary creations, a fact proving that "there were men upon the earth before Adam." 19 Prospero is able to achieve this by pointing out what he calls the lexical distinction between the Hebrew word for "God" (Elohim) and the Hebrew word for "Lord" (Jehovah). According to Prospero, a record of the work done by Elohim is found in Genesis, chapters 1 and 2, through verse 6, while Jehovah's efforts are documented in Genesis 2:6-25. Thus, in Prospero's view, there were two creations: the man and woman created in Genesis 1, whose chief occupation seems to be the maintenance of animals, and the man and woman created in Genesis 2, who are to be primarily engaged in agricultural pursuits, as their task is to keep the garden. But who exactly were these pre-Adamites? With the help of "modern science" (8), Prospero gives the following answer:

The preadamites were Mongols and Negroes, together with their mixed progeny. Created male and female, and in many pairs, they multiplied rapidly, exterminated the wild beasts, and replenished the earth with beings of their own species, penetrating into every land. (8)

Having confirmed the presence of Negroes and Mongols before Adam and Eve, Prospero can brush aside the "superstitious" reading of Genesis in which a serpent tempts Eve, and instead posit that "the tempter was a preadamite, perhaps a negro" (15). And though this "perhaps" seems to qualify his statement, Prospero's subsequent association of the tempter with a "witch-doctor" all but erases that qualification: the temptation "presents a vivid picture of an African medicine-man, or conjurer, with his 'grey dissimulation,' whispering his diabolical temptation into the ear of unsuspecting Eve" (15). Significantly, Prospero eroticizes the scene; the proximity required by the whispering presents a picture of pre-conjugal small talk.

Prospero's account of the temptation is certainly more explicit than Ariel's, but it does not approach the mini-romance sketched by A. Hoyle Lester in The Pre-Adamite, or Who Tempted Eve (1875). Lester's description is explicitly sexual, and grants to Eve an agency often denied her in other accounts. This white female agency, and the white male fear it evokes, will prove tremendously important to later accounts of the temptation scene. Lester begins by establishing a context for Eve's transgression, one in which she is portrayed as a bored and 
frustrated woman on the loose. Eve had become "wearied with the monotony that daily surrounded her. ... The presence of Adam had no doubt become irksome, and his voice, for the time, had ceased to fill the aching void that agonized her tender heart." ${ }^{20}$ Lester describes Eve's subsequent wandering in the language of sexual desire. She wanted to

explore the farther limit of her territorial domain, she wandered far along meandering brooks, and plucked strange flowers to while away the slowfleeting moments, and slaked her thirst at gushing fountains where she dreamed no mortal had yet partaken thereof. (22)

Eve's quest here is certainly sexual (the slaking of thirst at gushing fountains, for example). But hers, as portrayed by Lester, is a sexual desire imbricated with her craving for the exotic, the different. She seeks the "farther limit." She plucks "strange flowers." The eroticism of this passage is deeply entwined with its exoticism, setting the stage for Eve's ultimate encounter with the tempter, who in Hoyle's account is a Mongol, belonging "most assuredly to the highest order of the inferior races" (22). ${ }^{21}$

Eve, "innocent and unsuspecting," meets a "stranger," who is taken with her naked beauty. Eve bends her "attentive ear" in "enchanting conversation" with this "son of perdition," who came to her in "manly form, stately and erect" $(22,24)$. According to Lester, Eve and the tempter "met often and lingered long in some solitary shade by rural founts" (25). The temptation was not an isolated moment, but rather resulted from a courtship of sorts, a much more gradual seduction:

And this gay deceiver spoke of the germ in the human heart where affection springs, ... and of love with its operations on the tender heart, and said, Partake of the forbidden fruit: "Then shall your eyes be opened, and ye shall be as gods, knowing good and evil."

Eve, poor woman, yielded to the evil machinations of this seductive deceiver. She rose from the mossy couch a wiser but a fallen creature, and returned to the presence of her lawful companion disrobed of virtue, that precious jewel, the brightest ornament of her sex. (25)

This encounter, which Lester describes as "intercourse or intimacy," resulted in the birth of Cain, that "mongrel offspring" (26).

What interests me most about the above passage is the slippage between the tempter's command to "partake of the forbidden fruit" and Eve's subsequent rising from the "mossy couch." Nowhere in this passage is the Tree of Knowledge mentioned, where the "forbidden 
fruit" allegedly hung. This silence leads us to a syntactic discovery: the tempter's command results not in the eating of the apple, but sexual intercourse. In this account, the forbidden fruit literally becomes the Mongol's penis. The implicit story told by Ariel and others of "black" sexual seduction is here made explicit. ${ }^{22}$

The zenith of the pre-Adamite/tempter theorizing was reached in 1902 with the publication of Charles Carroll's mammoth The Tempter of Eve - or-The Criminality of Man's Social, Political, and Religious Equality with the Negro, and the Amalgamation to which these Crimes Inevitably Lead. With seventeen chapters, nine illustrations, and a total of 503 pages, Carroll's work was the most extensive to be written on the subject. The Tempter of Eve was published by the Adamic Publishing Company, a St. Louis religious press, and it followed by two years Carroll's more widely-known work, The Negro A Beast, published by another St. Louis firm, The American Book and Bible House. ${ }^{23}$ While little information exists concerning the circulation and reception of The Tempter of Eve, anecdotal accounts suggest that The Negro A Beast was widely circulated, particularly in the South. Writing in the North American Review in 1905, Edward Atkinson called Beast "the most sacrilegious book ever issued from the press in this country," and claimed that it was "securing a very wide circulation among the poor whites of the Cotton States." ${ }^{24}$ And in Christian Reconstruction in the South (1909), H. Paul Douglass tells of being offered Carroll's Beast through a door-to-door subscription campaign. Douglass attributes an unfortunate popularity to Carroll's book: "During the opening years of the twentieth century it has become the Scripture of tens of thousands of poor whites, and its doctrine is maintained with an appalling stubbornness and persistence." 25 This popularity was so disturbing to a group of Texas Baptists that they passed a resolution at their convention in 1902 condemning Carroll, and urging "our ministers, teachers, and membership everywhere to expose and denounce the insulting and outrageous book, now circulating in the South."26

While The Negro a Beast brought Carroll a certain notorious fame, he saw The Tempter of Eve as his crowning achievement, a grand summation of his views on Negro inhumanity. ${ }^{27}$ Those views were absolutely congruent with a large cross-section of public opinion on the "race question" at the turn of the century-particularly in the South. As George Fredrickson has argued, the period from the 1880s to around 1910 can be seen as struggle between two different strains of Southern 
racism: the Negrophobes and the accommodationists. The Negrophobes, who tended to dominate Southern opinion on the matter, saw blacks as a degenerating population, the inevitable victims of Darwinian struggle. ${ }^{28}$ This view depended upon an image of the Negro as "beast," and it was this image which both of Carroll's works intended to document and propagate.

In pre-Adamite theory Carroll found the perfect path to such an image, as did others. As Forrest G. Wood notes, two works by Carroll's contemporaries adopted similar strategies: William H. Campbell's Anthropology for the People: A Refutation of the Theory of the Adamic Race Origin of All Races, by a Caucasian (1891) and Alexander Harvey Shannon's Racial Integrity and Other Features of the Negro Population (1907) ${ }^{29}$ Further, Carroll provided himself with a degree of scientific respectability by citing selected passages from Alexander Winchell's Preadamites, Or a Demonstration of the Existence of Men before Adam (1880). Winchell was a professor of geology and paleontology at the University of Michigan, and so provided Carroll with an accredited scientific grounding for his racist theology. ${ }^{30}$

Tempter adds new fuel to the pre-Adamite fire in two interesting ways. While Carroll concurs with many of his predecessors in casting a Negro in the role of the tempter, he makes an intriguing revision in the drama of seduction, further highlighting the dangers of this imagined commerce between white and black in the garden. In addition, Carroll stands outside of the previous anti-black theorizing by reason of his identity-he was, by some accounts, a black man. I want to leave this second distinction in suspension until my conclusion.

The primary point of interest in The Tempter of Eve concerns the identity of the tempter promised in the work's title. Calling the numerous theories previously advanced on the question "more or less absurd," Carroll goes on to catalog the various versions of the story, discrediting the notion of the serpent as an agent of the devil, and the theory that the tempter was "an orang" capable of speech, also in the service of Satan. ${ }^{31}$ Since Carroll refuses to acknowledge that such a "Satanic Majesty" even exists (a product, he says, of the "grossest ignorance and superstition"), he insists that the tempter was an independent agent acting purely in the interest of coercing Eve into a violation of Divine law (402).

And who was this tempter? Who would have such an independent motivation? Like others before him, Carroll believes that the tempter 
was indeed a Negro. Unlike his predecessors, however, Carroll's tempter is "a negress, who served Eve in the capacity of maid servant" (402). Through a cunning work of verbal fiat, this negress "instilled into [Eve's] mind distrust of God; engendered in her heart discontent with her position; and aroused in her nature the unholy ambition that she and her husband "be as gods"" (404). According to Carroll, the Negress's clear status as an animal or beast required a duty in Adam and Eve "to control it in common with the rest of the animals" (405). Instead, "Eve accepted the negress as her counselor, and allowed the negress to control her" (405). The eating of the forbidden fruit was the couple's "second offense"; their first was accepting "the negress as their counselor," an act in which "they necessarily descended to social equality with her" (405-6). This, concludes Carroll, "reveals the startling fact that it was man's social equality with the negro that brought sin into the world" (406).

It is important to remember, however, that this "social equality" is not itself the ultimate sin. Rather, it simply makes possible (or even inevitable) the "most infamous and destructive crime known to the law of God"-amalgamation (406). And it is this possibility that Carroll's regendering of the tempter seeks to avoid, at least at the level of representation. We have seen the anxiety produced by the imaginings of Eve's encounter with a black man in the garden, and we have seen the various narratives that result from this anxiety, ranging from Ariel's relative silence on the issue, to Prospero's more explicit depiction of sexual intercourse. Carroll avoids the imputations on Eve's chastity by substituting a cunning black woman for the over-sexed black man. Blackness still stands in for seductive evil, but the terms of the seduction, and thus its meaning, have been changed.

Carroll's decision to include a visual representation of the temptation scene (see fig. 1) offers one possible explanation for his view of the tempter as a woman. ${ }^{32}$ This illustration literalizes the temptation scene in a way far more graphic than the discursive versions of Carroll's predecessors. Its primary emphases are on the stark white/black contrast and the participants' nudity - a nudity always assumed in the accounts of the temptation, but seldom rendered graphically. Eve's femininity is obvious, though hidden from the viewer by a rather surprising shock of hair which flows down her front. This hair, meant to hide breasts and genitalia from the viewer, does nothing, however, to cloak Eve's body from the tempter, as the partial appearance of Eve's 


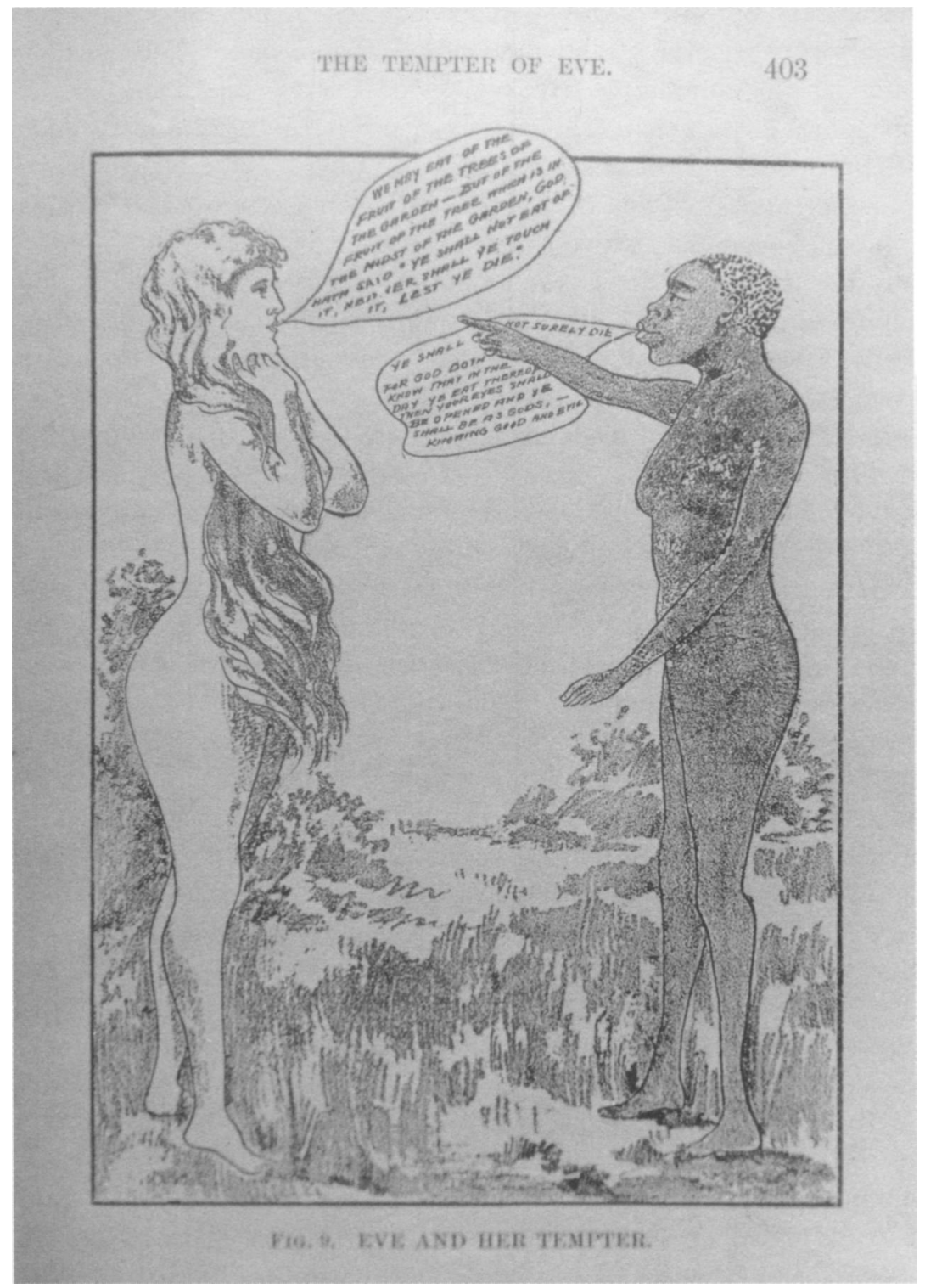

Figure 1.

left breast makes clear. The hair preserves the reader's modesty-not the tempter's, and not Eve's. In contrast to Eve, the tempter's gender is less obvious, and thus less in need of cover (a need rendered doubly 
unnecessary by "the Negro's" supposed lack of modesty). There is nothing very "feminine" about the tempter's appearance. The lines are straighter, in contrast to Eve's obvious curves, and there is the appearance of facial hair. The artist has attempted to bestow breasts upon the tempter, but the effect is closer to that of well-developed pectorals. ${ }^{33}$

In short, the presence of this illustration in the midst of Carroll's argument accomplishes two things. The decision to illustrate graphically the temptation scene foregrounds a nudity that simultaneously requires the absence of black masculinity. What can be rendered in words (Prospero's version, for example) becomes more dangerous as a visual-in fact, becomes impossible. And so the visual representation requires the erasure of black male sexuality. And yet, the picture does not fully accomplish the goals that Carroll's argument requires. The narrative move from male tempter to female tempter, accomplished in words, does not succeed visually. It is as if the lingering vestiges of black male sexual threat resurface in the tempter's inability to appear female in the same way as Eve. Absent actual male genitalia, the tempter still appears male here, further encoding the historical conflation of blackness with maleness. ${ }^{34}$

Upon second look, however, it becomes apparent that male genitalia are not really absent from the illustration. The tempter's left forearm, protruding from his/her pelvis, stands in for the absent black penis. Its angle and size suggests semi-tumescence; the shape of the hand further signifies the absent presence of the glans. And upon third look, yet another transformation occurs. The tempter's left fist, the head of the penis, decidedly resembles the head of a snake-a serpent. What we have, then, is a triple conflation. That which Carroll works so hard to separate ultimately resists such disentangling. Attempting to show us a black female tempter, this illustration cannot do so without reinscribing the forcibly removed black penis-an inevitable return of the repressed. Further, this black male sexual threat-which in other accounts replaces the "absurd" notion of "serpent as tempter"-here becomes indistinguishable from the threat of snakes. The black woman whose very existence allows the picture disappears from it entirely, leaving only the cultural residue of black male sexuality-the protruding black penis, the soon-to-strike, yet somehow alluring, snake. ${ }^{35}$

This quick slippage from female to male is made possible by the rather surprising discontinuity between Carroll's tempter and the prevailing image of the black female during the nineteenth century, the 
"Hottentot Venus." Known primarily for her abnormally large buttocks and genitalia, the image of the Hottentot Venus crystalized white fears of black female sexuality as simultaneously pathological and corrupting, and did so primarily through the visual language of sexual difference. The fact that Carroll's tempter is far removed from this conventional iconography of black female lasciviousness further demonstrates that his interest in this black woman is to some extent a dodge-a cover for his greater interest in the sexual temptation of black masculinity. Giving us this "mannish" female tempter rather than the exaggerated, pathological, and more easily recognizable femininity of the Hottentot, Carroll keeps black masculinity relatively intact and retrievable. ${ }^{36}$

And yet, while the female tempter disappears from the scene, I do not want to suggest that the threat she represents is not real. Black masculinity was not the only guise in which blackness produced defensive contortions in the white imaginary. ${ }^{37}$ Taking a speculative leap, I want to attach a historical identity to Carroll's unnamed and menacing female tempter. By doing so, the values at stake in this representational/racial crisis will become clearer. Carroll's work appeared in historical proximity to ghe writing and activism of Ida B. Wells, perhaps the most famous and effective anti-lynching activist of the 1890s. Wells, an African American woman, achieved national prominence in 1892 when she published a letter in her own newspaper, The Free Speech, questioning the always assumed linkage between interracial rape and lynching. Wells attacked this linkage by granting (or more accurately, returning) to white women an agency denied them in what Robyn Wiegman has called the "rape mythos." 38 In an editorial that brought death threats against her, Wells offered the tabooed suggestion that alliances between white women and black men were rarely the result of force:

Nobody in this section of the country believes the old thread bare lie that Negro men rape white women. If Southern white men are not careful, they will over-reach themselves and public sentiment will have a reaction; a conclusion will then be reached which will be very damaging to the moral reputation of their women. ${ }^{39}$

And as she put it more explicitly in an expanded version of this initial editorial, "white men lynch the offending Afro-American, not because he is a despoiler of virtue, but because he succumbs to the smiles of white women." ${ }^{40}$ Thinking the author of the editorial to be Wells's male 
business manager, J. L. Fleming, the Memphis Scimitar suggested that it was the "duty of the whites to tie the author to a stake, brand him on the forehead and perform a surgical operation on him with a pair of shears." ${ }^{41}$ And as the Memphis Commercial wrote, "there are some things the Southern white man will not tolerate," such as "the obscene intimations" of this editorial. ${ }^{42}$ The Scimitar's assumption of male authorship is both interesting and revealing, and I will return to it shortly. For now, I simply want to highlight the visceral reaction that Wells's views brought forth. Why such a reaction? In part, Wells's work against lynching carried with it an implied acceptance of miscegenationist alliances - of voluntary sexual alliances between white women and black men. At the heart of the hysterical male response that greeted Wells's editorial lies what Jacquelyn Dowd Hall calls "an uneasiness over the nature of white women's desires," an uneasiness that lynching and anti-miscegenation laws attempt to mask. ${ }^{43}$ The strength of Wells's anti-lynching writing lies in her awareness of this uneasiness, and of its almost bottomless depth. As she writes in A Red Record (1895):

With the Southern white man, any mesalliance existing between a white woman and a colored man is a sufficient foundation for the charge of rape. The Southern white man says that it is impossible for a voluntary alliance to exist between a white woman and colored man, and therefore, the fact of an alliance is a proof of force. ${ }^{44}$

This suggestively returns us to the illustration included in Carroll's work. What are the real dynamics at work there? We begin with a black woman offering the fruit of knowledge to a white woman. If we emphasize the sameness of gender rather than the difference of race, we can see this moment as a potential feminist alliance that transgresses racial boundaries. The fruit of knowledge which the tempter offers suggests an entrance into the kind of public activism exemplified so clearly by Wells. We hear echoes of Carroll's fear in his disgusted claim that "Eve accepted the negress as her counselor" (405)-“counselor" signifying not merely a shifted power dynamic, but a new relationship of tutelage. In this reading, Wells brings politics to white women, and the result is an alliance that threatens both patriarchy and white supremacy. ${ }^{45}$

In an important sense, however, this fear that Wells's anti-lynching campaign might contaminate white women by inviting them into the political arena was radically misplaced. As Hazel Carby has argued, 
very few white women responded to the social critiques and activism of Wells, or to her sister activist, Anna Julia Cooper. ${ }^{46}$ Rather, as Marjorie Spruill Wheeler has shown, white women came to political activism primarily through the suffrage movement. ${ }^{47}$ And in the South, white suffragists consistently deployed a rhetoric that worked against black/ white feminist alliances by suggesting that the enfranchisement of white women would be the easiest cure for the "Negro problem," since this swelling of the ranks of white voters would counteract those black men enfranchised under the fifteenth amendment. Though the strategy ultimately failed, leading suffragists such as Rebecca Latimer Felton and Jean Gordon hoped that white racial fear might be the key to opening up the polls to white women, and in order to exploit this fear they consistently worked against the kind of reform pursued by Wells and others. Responding to the phenomenon of lynching, Felton said that "if it needs lynching to protect woman's dearest possession from the raving human beasts - then I say lynch: a thousand times a week if necessary." 48

The suffragists" "southern strategy" can be traced to their awareness of what Wheeler calls "the historical association in the minds of white Southerners between advocacy of the rights of blacks and feminism." 49 I want to suggest that the suffragists' failure to win the vote through their appeal to southern racism can be read as their inability to overcome this historical linkage between feminism and the post-war struggle for black civil rights. Southern whites associated white female activism with the same type of threat to whiteness that African Americans represented, and this association was too strong and too entrenched to yield much ground during a period of significant racial anxiety.

In fact, the illustration accompanying Carroll's text makes this point clearly. Despite the shortage of real alliances between black and white women, the mere hint of such an alliance triggers a contortion in the fields of phallic power and authority. The presence of Wells and others as politically active black women causes the illustration to change shape, so as to represent more accurately the psychic threat at work. The illustrator's inability to represent a black woman without suggesting the contours of black male sexual threat has its analogue in the Scimitar's assumption that the writer of the offending editorial must be a black man. The threat of castration (remember the "operation" and the "pair of shears"), which is intended to diminish the potency of black masculinity, actually endows the figure of Wells with that masculinity. 
This transmogrification is similar to that which enables what Wiegman calls the "lynch scenario," whereby castration actually depends upon "an intense masculinization in the figure of the black male as mythically endowed rapist." 50 Castration is only necessary when its antithesis-the overly endowed phallic Negro-has secured a troubled home in the white male imaginary.

This "intense masculinization" accurately describes the graphic change from black woman to black man witnessed in the illustration accompanying Carroll's text. The double miscegenation of the scene (black woman/white woman; black man/white woman) calls forth a similarly doubled response. Out of this scene come the dual possibilities of transracial feminist alliances and transracial sexual alliances. Both threaten the core of white supremacy, with its foundation in patriarchy. Just when Wells, whose anti-lynching activism implied an implicit approval of transracial sexual relationships, offers this forbidden knowledge to Eve, she disappears. And in her place is the black man whom Wells allegedly wanted Eve to meet. The thing Carroll fears most from Eve's proximity to the pro-amalgamationist Wells comes into being before his eyes.

As the illustration demonstrates, distinctions insisted upon and verbally enacted do not always behave themselves. Whereas Carroll sees history as one long conflict between God and man over "man's social, political, and religious equality with the negro" (228), it is possible to see The Tempter of Eve-and all of those tracts and pamphlets which precede it-as one long attempt to both document and erase black male sexual threat from the nation's collective white unconscious-from that primal scene in the Garden of Eden.

This attempted erasure of black masculinity brings me back to the question of Carroll's identity, which I mentioned earlier, only to defer. And in returning to the question I must defer again, though only partially, since historical information concerning Carroll's identity is sketchy at best. ${ }^{51}$ Carroll slips in and out of blackness, depending on the source..$^{52}$ In a picture of the author facing the title page of Tempter, Carroll appears to be a white man (see fig. 2). But given the fact that appearance tells us very little about racial identity-especially as it is defined by the law-this picture cannot be said to solve this puzzle. Whether Carroll was black, white, or some combination of the two, I cannot assert with any assurance.

What I can do, however, is use my inability to locate Carroll along 


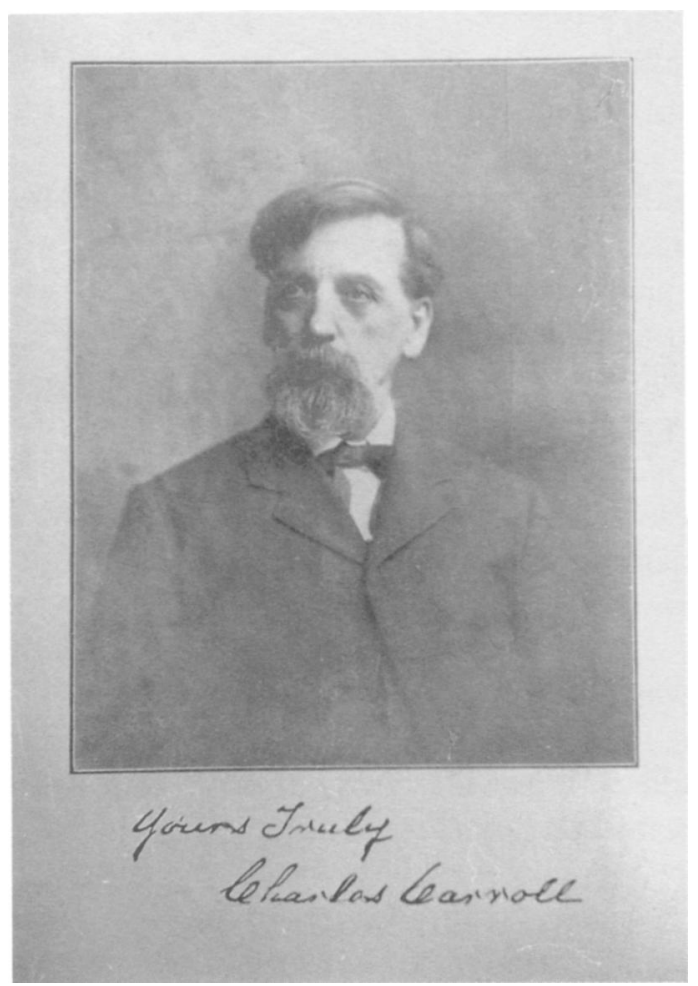

Figure 2.

either side of the color line as an opportunity to say a few things about the kind of reading I have been engaged in, and its limits. When able to fix an author's identity as white, I seem to have no problem reading outward from that identity, and working from assumptions that it supposedly provides. Presumably I could do the same thing if I decided that Carroll was indeed black. For example, I could position him as a representative of the so-called "self-hating negro," completely co-opted in mind and spirit by those whites whom he hopes to imitate. Or if I decided that he was a mulatto, I could argue that his fear and hatred of amalgamation amounts to nothing more than a theoretical attempt to jettison that part of himself which he sees as contamination. Or as a third option, I could suggest that Carroll's surreptitious strategy is to create blackness as a thing of cunning and power. By constructing this phantasmic figure of black power, Carroll ironically challenges whiteness as a site of knowledge and control. The "negro as beast," then, becomes a prototype for the Black Power Movement of sixty years 
later, a character in search of a Baraka play. ${ }^{53}$ Were it not for the overall tone of Carroll's massive work, this argument might be worthy of further consideration. As it stands, however, it does not ring true. My discomfort with all of these readings raises questions about my obvious comfort in reading outward so confidently from whiteness as an identity. Is whiteness so neatly packaged that it comes with a clear list of ingredients and instructions?

Well, yes and no. While I want to maintain a certain suspicion about the absolute legibility of whiteness, I do think its hegemonic power can render it readable in a way that blackness often is not. Carroll ventriloquizes whiteness as ideology, regardless of his skin color. And yet, he becomes invisible within the hyper-scriptedness of blackness as a false series of neat and legible categories. Not knowing where to "place" him, we do not quite know what to do with him.

And so I want to shift the emphasis from Carroll's identity to his identification, foregrounding the power of whiteness as ideology rather than skin color. ${ }^{54}$ While a white skin may make the ideology more useful to one, it is not necessary. As a way of seeing, a myth of power, an entire social structure, whiteness works precisely because of our inability to adequately "read" Charles Carroll—our inability to contain him by easy categorization. In contrast to the popular wisdom that whiteness can only exist within a clearly readable, binary structure (a wisdom I want to complicate rather than discredit), I am suggesting that absent such a structure its power actually intensifies in proportion to its invisibility. Unable to locate whiteness in or on the body of Carroll, we are left with the realization that it works best as unattached abstraction, as that which flows through us without staying in any one place for too long. Like a fugitive, it knows to keep moving.

The dilemma that Carroll represents, both as racial ambiguity and theologian, extends far beyond the moment of his writing. Asked to discuss the subject of miscegenation twenty-three years after The Tempter of Eve was published, W. E. B. Du Bois wrote that "the question of the extent to which whites and blacks in the United States have mingled their blood, and the results of this inter-mingling, past, present and future, is, in many respects, the crux of the so-called Negro problem." 55 The mingling of blood that Du Bois cites stands at the heart of the Garden-constituting the phantasmic pre-history of the specifically American mingling he addresses. The scene that Carroll cannot bring himself to witness becomes his obsession, the crux of his problem. 
But it is finally America's problem. In Playing in the Dark, Toni Morrison argues that "the fetishizing of color" undergirds much, if not all, of America's literary aesthetic. For Morrison, canonical American literature depends upon the "thunderous, theatrical presence of black surrogacy -an informing, stabilizing, and disturbing element" of a specifically white literary imagination. ${ }^{56}$ By black surrogacy Morrison means the unacknowledged, but never silent, Africanist presence that fuels so many white imaginings of the so-called "American experience." The classic American themes of freedom, autonomy, and individualism, Morrison argues, are in fact anything but free, autonomous, or individual. Rather, they only exist in the absent presence of their counterparts-slavery, for example-and thus are wholly dependent upon blackness for their place at the center of white America's literary musings about itself.

If Morrison is right in her insistence on a "dark, abiding, signing Africanist presence" in the American Eden (and I believe that she is), then of course there is a black tempter in the Garden. ${ }^{57}$ The nation could not imagine itself without him -or her, if we remember the illustration Carroll's argument depends upon, and the nervously disappeared threat of black female autonomy it represents. In the hands of Carroll's illustrator, we witness the birth and simultaneous death of the female tempter. Like a hazy hallucination, continually morphing in response to the needs and fears of the viewer, the cunning negress never really stood much of a chance. The political threat she posed to Carroll's sense of white patriarchy was real, but it could not approach the visceral reaction guaranteed in the white imaginary by the "erect" and "stately" (to borrow Lester's adjectives) form of black male flesh. Given Carroll's cultural moment, the picture of Eve and the temptress is somehow off. There is something missing that the culture requires. And in the blink of an eye, the snaking black penis returns, and the picture is complete. With the return of the repressed, the harmony of form and content is restored. Not wanting to see a naked black man in the garden, Carroll lacked other options. The black man was there, in the beginning. 


\section{NOTES}

I want to thank the following people for their astute and helpful comments on earlier versions of this article: Deborah E. McDowell, Eric Lott, Daylanne English, John David Smith, and the editors and referees at American Quarterly. Thanks also to Philip N. Dare for his help in procuring the necessary photographs.

1. W. E. B. Du Bois, The Crisis Writings, ed. Daniel Walden (Greenwich, Conn., 1972), 334.

2. Ibid., 335, 334.

3. Ibid., 335.

4. Frederick Douglass, The Life and Writings of Frederick Douglass, ed. Philip S. Foner, vol. 2 (New York, 1950), 295.

5. Agreeing with Nancy Leys Stepan and Sander L. Gilman, I am resisting the urge to refer to these ethnologists as "pseudoscientists" rather than scientists. As Stepan and Gilman argue, "calling scientific racism a pseudoscience ... allows scientists to refuse to confront the issue of the inherently political nature of much of the biological and human sciences, and to ignore the problem of the persistence of racial metaphors of inferiority in the sciences of today." "Pseudoscience" becomes a distancing rhetoric that covers over the political resonances and effects of so-called "mainstream" science. See Stepan and Gilman, "Appropriating the Idioms of Science: The Rejection of Scientific Racism," in The Bounds of Race: Perspectives on Hegemony and Resistance, ed. Dominick LaCapra (Ithaca, N.Y., 1991), 76.

6. Douglass, Life and Writings, 298.

7. Ibid., 291, 292. Written five years before Darwin's Origins of the Species, the ambivalence toward evolutionary thought that Douglass expresses here was to characterize his later relationship to Darwin's work. As he put it as late as 1883,

I do not know that I am an evolutionist, but to this extent I am one. I certainly have more patience with those who trace mankind upward from a low condition, even from the lower animals, than with those that start him at a high point of perfection and conduct him to a level with the brutes. I have no sympathy with a theory that starts man in heaven and stops him in hell.

See Frederick Douglass, The Frederick Douglass Papers, ed. John W. Blassingame, vol. 5, (New Haven, Conn., 1982), 129.

8. Douglass, Life and Writings, 293.

9. Charles Carroll, The Tempter of Eve; or, The Criminality of Man's Social, Political, and Religious Equality with the Negro, and the Amalgamation to Which These Crimes Inevitably Lead. Discussed in the Light of the Scriptures, the Sciences, Profane History, Tradition, and the Testimony of the Monuments (1902), in Anti-Black Thought, 1863-1925: "The Negro Problem," ed. John David Smith, vol. 6 (New York, 1993), xv. 10. For useful overviews of late-nineteenth-century white-supremacist thinking, see George M. Fredrickson, The Black Image in the White Mind: The Debate on AfroAmerican Character and Destiny, 1817-1914 (1971; Hanover, N.H., 1987); and John David Smith, An Old Creed for the New South: Proslavery Ideology and Historiography, 1865-1918 (Westport, Conn., 1985).

11. E. G. Squier, “American Ethnology,” American Review 9 (1849): 385, 386.

12. Antonio Gramsci offers another way to understand this struggle. My earlier reference to "common sense racism" is meant to suggest Gramsci's notion of common sense as a "chaotic aggregate of disparate conceptions," where "one can find anything that one likes." For Gramsci, common sense is itself a product of hegemony, and 
becomes a means through which oppression and inequality are naturalized. Gramsci is interested in the ways intellectual systems can tap the productive possibilities of common sense so as to create a new common sense, one that would be less conducive to systemic inequalities. In the context of the argument I am tracing here, then, common sense becomes the site where religion (which Gramsci calls "an element of fragmented common sense") and philosophy (an "intellectual order" for which we can read "science") contest for dominance. The shape of common sense as "an ambiguous, contradictory and multiform concept" makes it a rich space of cultural mediation where "truth" gets simultaneously created and distributed. See David Forgacs, ed., An Antonio Gramsci Reader: Selected Writings, 1916-1935 (New York, 1988), 345, 327, 346.

13. William Stanton, The Leopard's Spots: Scientific Attitudes Toward Race in American, 1815-59 (Chicago, 1960), 194.

14. I want to stress the allegorical nature of this narrative, and in so doing borrow Toni Morrison's insistence that allegory works by emptying history of its content. According to Morrison, one of the "common linguistic strategies" that white writers have used to "engage the serious consequences of blacks" is a "dehistoricizing allegory," one that renders historical and cultural tension mute before a larger, mythical contest between blackness and whiteness. The theorists of the Garden erased the specific history of slavery, and their own cultural moment, in order to stage their contemporary fears and concerns at a far-distant site, and in a larger-than-life symbology. See Toni Morrison, Playing in the Dark: Whiteness and the Literary Imagination (New York, 1992), 67-68. 15. Ariel, of course, is the good spirit of Shakespeare's The Tempest, co-inhabitant of the island with the savage Caliban.

16. Harrison Berry, A Reply to Ariel (1868), repr. in Anti-Black Thought, 8. As John David Smith points out, scholars have had difficulty confirming that Berry actually wrote this reply to Ariel. Maxwell Whiteman has suggested that an earlier volume attributed to Berry (Slavery and Abolitionism, as Viewed by a Georgia Slave) was possibly written by, or at least unduly influenced by, his master. And as Smith points out, Monroe N. Work's A Bibliography of the Negro in Africa And America does not identify Berry as a black author. See Whiteman's introduction to Berry's Slavery and Abolition (1861; Wilmington, N.C., 1977), and John David Smith's introduction to Anti-Black Thought, xxviii-xxix.

17. Ariel [Buckner H. Payne], The Negro: What is his Ethnological Status? Is he the Progeny of Ham? Is He a Descendant of Adam and Eve? Has He a Soul? Or Is He a Beast in God's Nomenclature? What Is His Status as Fixed by God in Creation? What Is His Relation to the White Race? (1867), in Anti-Black Thought, 45, 25, 45. Subsequent references appear in the text. Ariel's Adam-like naming of the Negro as a beast depends upon his translation of the original Hebrew term for "men." Gen. 4:26 describes a time when men "began . . . to call on the name of the Lord," and Ariel makes much of the word "began" here. Since Adam, Cain, Abel, and Seth "were all the men that were of Adam's race that were upon the earth at that time" (28), these "men" who suddenly began to call upon the name of the Lord "were negroes-the men so named by Adam when he named the other beasts and cattle" (28). This linguistic sleight of hand allows Ariel the distinction which his theory requires-the one separating the race of Adam from the race of "men."

18. Prospero was the Duke in Shakespeare's play who comes to rule over the slavish and deformed Caliban. This choice of pseudonym in response to Ariel clearly reveals the colonial power dynamic at work here. If we remember Harrison Berry's charge that Ariel's argument was "founded on the interest of the great diabolical slave power," this joint work of Ariel/Prospero becomes an appropriate metaphor for the viability of slavery as a social structure. Though a servant himself in Shakespeare's play, Ariel 
aligns himself not with Caliban, who is also a servant (though classed as a "slave"), but with Prospero, his master. As Jerry Phillips has argued, the difference between Ariel's status as "servant" and Caliban's as "slave" is necessary to the "architecture of whiteness." In Phillips' words, "In the logic of class conflict underpinning the play's dramatic action, Ariel must be seen as representing a counterrevolutionary position. Ariel is a servant, but instead of demonstrating solidarity with other servants and slaves, he looks on them with the eyes of the master. . . In the ideological profile of Ariel, we can see the repressive capability historically located in the colonial soldier, the overseer, the lowly 'white' man, who defends the house of the master against the violence of rebellious slaves." See Phillips, "Literature in the Country of 'Whiteness': From T.S. Eliot to The Tempest," in Whiteness: A Critical Reader, ed. Mike Hill (New York, 1997), 338, 341.

19. Prospero, Caliban. A Sequel to "Ariel" (1868), in Anti-Black Thought, 4. Subsequent references appear in the text.

20. A. Hoyle Lester, The Pre-Adamite, or Who Tempted Eve? Scripture and Science in Unison as Respects the Antiquity of Man (1875), in Anti-Black Thought, 22. Subsequent references appear in the text.

21. While I have highlighted the sexual nature of Eve's wandering, I should also mention its more overtly political aspect. Prospero, writing in the context of everexpanding feminist activism, offers Eve's wandering as a cautionary tale against a more general feminine move away from the domestic space. When women are not happy in the home, they are liable to take that unhappiness to the streets, in the service of voting rights, for example. I will return to this threat of feminist activism in my discussion of Charles Carroll.

22. My slippage from "Mongol" to "black" is not meant to erase ethnic distinctions, but to signal the ways in which non-white sexual threats got lumped together in these accounts. For all their care in disentangling the various "races," these theorists still felt a threat to whiteness from any non-white source. "Mongol" and "black" created the same fear, though the representations of that fear may differ in regard to degree.

23. The full title of this work is The Negro a Beast or "In the Image of God": The Reasoner of the Age, the Revelator of the Century! The Bible as it is! The Negro and His Relation to the Human Family!. The title-page copy continues:

The Negro a Beast, but created with articulate speech, and hands, that he may be of service to his master-the White man. The Negro not the Son of Ham, Neither can it be proven by the Bible, and the argument of the theologian who would claim such, melts to mist before the thunderous and convincing arguments of this masterful book. By Chas. Carroll, Who has spent fifteen years of his life, and $\$ 20,000.00$ in its compilation.

24. Edward Atkinson, "The Negro a Beast," North American Review 181 (1905): 202. 25. H. Paul Douglass, Christian Reconstruction in the South (Boston, 1909), 114.

26. B. R. Womack, “A Kind Word for the Negro,” Baptist Standard 14 (1902): 3.

27. This, despite the apparent failure of the Adamic Publishing Company. Tempter was the first in a series of books to be published in the Adamic Library, and it is safe to assume that this series never got off the ground. An advertisement included with Tempter mentions future publications on the Book of Revelation and the dangers of Spiritualism. If nothing more, this advertisement reveals Carroll's almost ludicrous ambition: "The fourth, fifth, sixth, seventh and eighth books of this series will each be devoted to a history of one of the five continents from the Deluge to the Twentieth century," all to be written by Carroll himself (504). These works apparently never materialized, and the Adamic press does not appear in turn-of-the-century St. Louis directories. 
Carroll would be pleased to know, however, that The Tempter of Eve reappeared in the 1970s-not in a scholarly edition, but in an enthusiastic reprint dedicated to Carroll's debunking of evolution. As its editor writes,

this work is a scientific and scriptural refutation of the atheistic theory of evolution, or descent. ... Read it and be warned - take heed - and move quickly and decisively to save our country and our descendants from a destruction that has befallen so many countries and peoples down through the ages. (vi)

See Charles Carroll, The Tempter of Eve: a Book of Absorbing Interest and Profound Concern to Everyone (Eufala, Ala., 197-?), a copy of which is located in the Auburn University Library.

28. Fredrickson argues that the accommodationists failed in influence largely because "they were, for the most part, intellectuals-clergymen and professors-attempting in vain to shape public policy in a profoundly antiintellectual society" (297).

29. Forrest G. Wood, The Arrogance of Faith: Christianity and Race in American from the Colonial Era to the Twentieth Century (New York, 1990), 241.

30. See Fredrickson, The Black Image in the White Mind, 277. Whether Carroll's religious arguments were generally accepted remains somewhat of a mystery. Woods suggests that Carroll's ideas "were popular only among the most fanatical religious racists" (241). And yet, I am suspicious of arguments which cast Carroll-and other racial extremists - entirely beyond the pale. Firmly of his moment, Carroll helps us to see the more commonplace realities which extremism is designed, in part, to cover up, and thus to facilitate. Whether Carroll's theory of the tempter gained wide currency is ultimately less important to me than the ways in which Carroll's version of the story shared common assumptions with—and made visible—a more "mainstream" culture of racism.

31. Carroll, Tempter of Eve, 400. Subsequent references appear in the text.

32. I have been unable to determine the artist responsible for this illustration.

33. It could be argued that the illustration does not de-feminize the tempter so much as it dehumanizes her. In other words, the tempter's difference from the obviously feminine Eve is not a difference of gender, but of species. Carroll, for example, might say that the female beast is not feminine in the same way as the female human. And while this could partially explain the tempter's appearance, the issue of gender should not be allowed to drop out of the equation, since gender does indeed play a role in the imagining of this supposed difference in "species." The tempter's lack of femininity cannot be fully separated from her lack of humanity. Rather, these qualities function in something like a dialectical relationship, where the absence of one contributes to and is reinforced by the absence of the other.

34. This conflation is both obvious and complicated. The notion that blackness is always already gendered male has a lengthy history, and is usually generated, in part, by racist fascination with black male sexuality. But since racist cultures often want things both ways, it is not surprising that blackness, in certain contexts, appears first and foremost as a female property. One of the respondents to the Ariel debate makes this point visually apparent when he provides a pictorial hierarchy of the races, in which the only examples gendered female are the Ethiopian and the Negro. Since the argument's emphasis is on the gradations of weakness and stagnation, it makes sense for this writer to see Ethiopians and Negroes as women-passive bodies reflecting the end of the family line.

35. James Fenimore Cooper's The Last of the Mohicans (1826; Albany, N.Y., 1982) offers a resonant analogue to this conflation of ethnic and reptilian threats. When Cora and Alice Munro are captured by the Indian Magua, who then threatens Cora with 
marriage, Natty Bumppo arrives to "save these tender blossoms from the fangs of the worst of sarpants" (105). For more on the sexual and racial politics in the territories, see Leland S. Person Jr., "The American Eve: Miscegenation and a Feminist Frontier Fiction," American Quarterly 37 (winter 1985): 668-85. The material Person examines provides somewhat of an antecedent to the material I read here, since novels of the frontier often placed white women (American Eves carving out new territory) in dangerous or romantic proximity to Indians.

36. For more on visual representations of the Hottentot Venus see Sander L. Gilman, "Black Bodies, White Bodies: Toward an Iconography of Female Sexuality in Late Nineteenth-Century Art, Medicine, and Literature," in "Race," Writing, and Difference, ed. Henry Louis Gates, Jr. (Chicago, 1985).

37. In fact, Gilman links the corrupting sexuality of black women-specifically the Hottentot-to lesbianism. As Gilman points out, a standard gynecological handbook of the late-nineteenth century suggested that the "Hottentot Apron" (the supposedly deformed labia of the Hottentot) was responsible for the "overdevelopment of the clitoris," which the handbook associates with the "'excesses"” of "'lesbian love"" (237). Though this linkage of black femininity to lesbianism could have intriguing ramifications for my reading of Carroll's temptation scene, I am reluctant to pursue them. While Carroll's tempter corresponds to certain images of the "mannish woman," that is, the lesbian, the linkage between black female sexuality and lesbianism which Gilman traces depends upon the physically observable and pathological genitalia of the Hottentot. Since Carroll's tempter does not share the Hottentot's "excessive" physiology, the link from "black female" to "lesbian" in Carroll's illustration is not as obvious as it may first appear.

Esther Newton's influential discussion of the "mannish lesbian" offers another way of introducing lesbian sexuality into a discussion of Carroll's illustration, though here too I am not persuaded that lesbian temptation stands at the center of the picture. Describing women whose behavior or dress contained "masculine" elements, Newton writes that "from about 1900 on, this cross-gender figure became the public symbol of the new social/sexual category "lesbian"' (283). As Newton points out, the assumed link between "mannish" behavior and lesbianism can also be found in medical discourse of the late-nineteenth century, particular the writings of influential sexologists Richard von Krafft-Ebing and Havelock Ellis. And yet, neither Newton, KrafftEbing, nor Ellis consider how this linkage between mannishness and lesbianism gets complicated by race-or more specifically, by blackness. While it is safe to assume that mannish representations of bourgeois white women carried associations of lesbian degeneracy (Radclyffe Hall's Stephen Gordon is the most obvious literary example), it does not follow that similarly masculine black women could be read in the same way. In other words, mannishness in bourgeois white women is seen as degenerate because it represents a fall from a so-called purely feminine state; under the cultural logic of white racism, however, black women had no such state from which to fall in the first place. See Newton, "The Mythic Mannish Lesbian: Radclyffe Hall and the New Woman" in Hidden From History: Reclaiming the Gay \& Lesbian Past, ed. Martin Bauml Duberman, Martha Vicinus, and George Chauncey, Jr. (New York, 1989).

Finally, Lynda Hart has argued that the category of lesbian has historically been marked as white, which she says is "an inheritance from nineteenth-century sexology and criminology that became further encoded in the discourse of psychoanalysis." See Hart, Fatal Women: Lesbian Sexuality and the Mark of Aggression (Princeton, N.J., 1994), 106.

38. Wiegman uses this phrase to signify the multiplicity of stories that govern and attach themselves to actual and narrative instances of rape and lynching in the 
nineteenth and twentieth centuries. Tracing a shift in the cultural framework through which rape and lynching were viewed, Wiegman highlights the "performative" and "specular" aspects of lynching at the end of the nineteenth century, insisting that we understand lynching as "a disciplinary activity that communalizes white power while territorializing the black body and its movement through social space." See Robyn Wiegman, American Anatomies: Theorizing Race and Gender (Durham, N.C., 1995), 13. For an earlier and indispensable treatment of lynching as a literary figure, see Trudier Harris, Exorcising Blackness: Historical and Literary Lynching and Burning Rituals (Bloomington, Ind., 1984).

39. Ida B. Wells-Barnett, Selected Works of Ida B. Wells-Barnett, ed. Trudier Harris (New York, 1991), 17.

40. Ibid., 19.

41. David M. Tucker, "Miss Ida B. Wells and Memphis Lynching," Phylon 32 (summer 1971): 117.

42. Ibid., 117.

43. Jacquelyn Dowd Hall, “The Mind That Burns in Each Body': Women, Rape, and Racial Violence," in Powers of Desire: The Politics of Sexuality, ed. Ann Snitow, Christine Stanswell, and Sharon Thompson (New York, 1983), 336.

44. Wells-Barnett, Selected Works, 145.

45. The reverse of this conspiratorial scenario would come some eighty years later, when black men would blame white feminists for turning "their women" against them. Reviewing Alice Walker's The Color Purple, Darryl Pinkney argued that the novel's appeal "does not lie in its text, but, through representing the black woman's experience in the popular feminist vocabulary, in its power as a symbol of the reconciliation between black women and white women in the feminist movement." The vitriol spilled on Walker by Pinkney and others suggests their real fear of such a "reconciliation," however much a paranoid fantasy it might be. The repetition (with a racial reversal) of this conspiratorial vision of feminist alliances may say more about the underlying logic of patriarchy than it does about race relations. See Darryl Pinkney, "Black Victims, Black Villains," New York Review of Books, 29 Jan. 1987, 18. For other examples of this criticism see Mel Watkins, "Sexism, Racism and Black Women Writers," New York Times Review of Books, 15 June 1986; Philip M. Royster, "In Search of Our Fathers' Arms: Alice Walker's Persona of the Alienated Darling," Black American Literature Forum 20 (winter 1986): 347-70; and Stanley Crouch's review of Toni Morrison's Beloved, “Aunt Medusa," The New Republic 194 (Oct. 1987): 38-43.

46. Hazel Carby, “'On the Threshold of Woman's Era': Lynching, Empire, and Sexuality in Black Feminist Theory," Critical Inquiry 12 (autumn 1985): 270. In fact, white women did not become a significant part of anti-lynching activism until the formation of the Association of Southern Women for the Prevention of Lynching in 1930, under the leadership of Jessie Daniel Ames. For more on this organization and its leader see Jacquelyn Dowd Hall, Revolt Against Chivalry: Jessie Daniel Ames and the Women's Campaign Against Lynching (New York, 1993).

47. Marjorie Spruill Wheeler, New Women of the New South: The Leaders of the Woman Suffrage Movement in the Southern States (New York, 1993).

48. Ibid., 103.

49. Ibid., 111.

50. Wiegman, American Anatomies, 83.

51. According to Tempter's title page, Carroll was apparently living in St. Louis at the time of its publication. A search of St. Louis directories from the late 1890 s to the early 1900s reveals several Charles Carrolls, most of whom were laborers. Checking this information against Carroll's known birth date (1849), it is possible to isolate a Charles 
C. Carroll, who was a salesman born in Missouri to Virginia-born parents. The 1900 census shows this Carroll and his wife living with his sister Maggie Carroll Ennis and her husband James Ennis. I am grateful to Jean E. Meeh Gosebrink at the St. Louis Public Library for making this information available to me.

52. For example, Eric Sundquist describes him as a mulatto, while Joel Williamson labels him a "black man." George Fredrickson and Forrest G. Wood make no mention of Carroll's race, leaving the assumption that he was white. John David Smith, editor of the collection which reproduced The Tempter of Eve, also provides no biographical information on Carroll, and seems to assume that Carroll was white. M. B. Thompson, a black respondent to Carroll's work, and Carroll's contemporary, also operates on the assumption that Carroll was white. Finally, Monroe N. Work's generally reliable Bibliography of the Negro in Africa and America does not list Carroll as either a Negro or a mulatto. See Eric Sundquist, To Wake the Nations: Race in the Making of American Literature (Cambridge, Mass., 1993), 395; Joel Williamson, The Crucible of Race: Black-White Relations in the American South Since Emancipation (New York, 1984), 119; Wood, The Arrogance of Faith; Smith's intro. to Anti-Black Thought; Thompson, The Negro, Not a Beast; and Monroe N. Work, Bibliography of the Negro in Africa and America (New York, 1928), 576, 578.

53. Harrison Berry, the black respondent to Ariel mentioned earlier, makes a similar point when he takes Ariel's argument on its own terms, unpacking the power dynamic it reveals. Referring to Adam and Eve's deception at the hand of the black tempter, Berry asks, "does it not look like the one kinky headed Negro had more sense than the straight-haired, high foreheaded, sharp nosed, think lipped, white skin, Adam and his wife had?" (9). Ariel's argument, according to Berry, proves not only that the Negro "must have been Adam's superior by far," but that "his race is superior to Adam's race to-day" (10).

54. Kobena Mercer makes a similar point in a more recent context. With Clarence Thomas as his text, Mercer writes, "The dangerous simplifications of identity politics consistently fail to recognize that the political problem of power represented by straight white males is a problem not about persons but about ideological subject-positions that reproduce relations of oppression." "Only by making a tactical shift from 'identity' to "identification," Mercer continues, "can we preempt the perpetuation of a public discourse in which white men remain at the center. "See Kobena Mercer, "Fear of a Black Penis," Artforum 32 (Apr. 1994): 81, 122.

55. W. E. B. Du Bois, Against Racism: Unpublished Essays, Papers, Addresses, 18871961, ed. Herbert Aptheker (Amherst, Mass., 1985), 96.

56. Morrison, Playing in the Dark, 80, 13.

57. Ibid., 5 